\title{
Potential effects of global climate warming on brook trout growth and prey consumption in central Appalachian streams, USA
}

\author{
Robert D. Ries, Sue A. Perry* \\ National Biological Service, West Virginia Cooperative Fish and Wildlife Research Unit, Box 6125, Division of Forestry, \\ Morgantown, West Virginia 26506-6125, USA
}

\begin{abstract}
The effects of global warming trends on growth and food consumption rates for a brook trout Salvelinus fontinalis population were simulated with a bioenergetics model. We examined the hypothesis that improved growth conditions during cooler months will offset the opposing effects of extreme temperatures during the summer. Annual growth increments of brook trout were determined from a population in a high elevation stream in West Virginia, USA, and baseline stream temperatures were measured in mid to high elevation streams. The mean annual stream temperature was increased by 2 and $4^{\circ} \mathrm{C}$ to simulate the effects of climatic warming. Brook trout populations at high elevations in the Appalachian Mountains could either benefit from increased growth rates in spring and fall, or suffer from shrinking habitat and reduced growth rates in summer, depending on the magnitude of temperature change and on food availability. An increase of $2^{\circ} \mathrm{C}$ or less could very likely increase brook trout growth, but the effect of larger temperature increases is less predictable due to greater dependence on higher prey production. A 15 to $20 \%$ increase in food consumption would be required to maintain present rates of growth with an increase of $2^{\circ} \mathrm{C}$, and 30 to $40 \%$ more food would be required with an increase of $4^{\circ} \mathrm{C}$
\end{abstract}

KEY WORDS: Brook trout · Bioenergetics model - Global warming Temperature effects

\section{INTRODUCTION}

The concentration of $\mathrm{CO}_{2}$ in the atmosphere has increased by $11 \%$ over the past $30 \mathrm{yr}$ and is predicted to double sometime in the next century (Hengeveld 1990). If $\mathrm{CO}_{2}$ and other greenhouse gases reach projected levels, most climate models predict that the global mean annual temperature of surface air will rise by 2 to $4^{\circ} \mathrm{C}$ (Cess \& Potter 1984;. The annual temperature increase in the southern Appalachian region projected with the Goddard Institute for Space Studies model is $4.8^{\circ} \mathrm{C}$, which is intermediate to other scenarios (Meisner 1990b). Average groundwater temperatures are expected to increase with rising air temperature and can be approximated by adding $1.5^{\circ} \mathrm{C}$ to the local atmospheric mean (Meisner 1990a).

\footnotetext{
- Addressee for correspondence.

E-mail: sperry@wvnvm.wvnet.edu
}

Water temperature affects the energy budget of growth and metabolism in fishes (Brett 1979) and influences the suitability of habitat for a fish species through metabolic constraints (MacCrimmon \& Campbell 1969, Tonn 1990). The brook trout Salvelinus fontinalis is a cold-water species dependent on waters colder than $24^{\circ} \mathrm{C}$ (MacCrimmon \& Campbell 1969). Under ideal conditions, maximum growth rates for brook trout are reported at temperatures between 13 and $16^{\circ} \mathrm{C}$ (Baldwin 1956, McCormick et al. 1972). Mortality rapidly increases at $18^{\circ} \mathrm{C}$ and above (Peterson et al. 1979), with an upper lethal limit of $25^{\circ} \mathrm{C}$ (Fry et al. 1946).

The southern margin of native brook trout habitat in North America is bounded by stream temperatures that approach lethality during the summer (Meisner 1990a). The native range of brook trout in the United States extends from the Great Lakes region to the East Coast, and southward along the Appalachian Moun- 
tains. Summer water temperatures restrict brook trout in the Appalachian region to cold waters found at high elevations (Bivens et al. 1985, Meisner 1990b) or streams fed by springs (Meisner et al. 1988). Consequently, suitable thermal conditions for brook trout in the Appalachian region are found in the upper reaches of watersheds, leaving little room for upstream migration to avoid high summer temperatures.

The extent of cold-water habitats will decrease with global warming (Meisner 1990a, b), but the response of brook trout populations to warmer temperatures has not been fully addressed. Higher stream temperatures could either increase growth rates of brook trout in colder waters by shifting temperatures closer to the optimal range, or decrease growth rates (and brook trout thermal habitat) by pushing water temperatures above the optimal range. The effects of increased temperatures on brook trout growth and survival depend on their energetic requirements and constraints, including the degree of food limitation in the environment. All food energy acquired by an organism is either used in metabolic processes, lost as waste, or synthesized into new tissue as growth (Adams \& Breck 1990). Growth occurs when caloric intake exceeds energetic costs. At the optimal temperature, rates of consumption, digestion, metabolism, and excretion are balanced so that growth is maximized. When food is limited, highest growth rates occur at temperatures below the optimal range due to decreased energetic costs.

Bioenergetics models (e.g. Winberg 1956, Elliott 1976, Kitchell et al. 1977, Rice et al. 1983, Hewett \& Johnson 1992) provide a framework to investigate the physiological response of brook trout to changes in temperature and prey availability. Bioenergetics models partition physiological components into an energy budget that balances energy gained from food consumption with energy expended for metabolism, waste losses, and growth. Given any 3 of these variables, bioenergetics models can be used to predict the fourth. We used the bioenergetics model of Hewett \& Johnson (1992) to investigate the possibility that higher stream temperatures would increase growth rates of brook trout populations in high elevation streams. We tested the hypothesis that higher growth rates will occur during cooler seasons from increased temperatures, and offset the effects of extreme summer temperatures. Growth and diet of brook trout at present (baseline) temperatures were compared to growth and diet with 2 and $4^{\circ} \mathrm{C}$ increases in the annual mean. Three scenarios were simulated: (1) Change from baseline growth and baseline consumption when the feeding rate (total intake/potential intake) is fixed and temperature is limiting. With a fixed feeding rate, total consumption varies as a function of temperature and fish size, and growth is affected. by the combined effects of tempera- ture and total consumption. (2) Change from baseline growth rates when food abundance is fixed. Total food consumption was fixed at baseline levels. As temperatures increase, a smaller proportion of the diet is available for growth, and growth declines proportionally to increased metabolic costs. The change in growth is a relative measure of food limitation, or the amount of stress associated with higher temperatures. (3) Change from baseline consumption when growth is fixed at baseline levels. With higher temperatures, fish will require a greater amount of food to reach the same size, and prey abundance may not be sufficient to meet the demand. Increased consumption is an indicator of starvation risk, or a relative measure of increased productivity required to maintain present growth levels.

\section{METHODS}

Annual growth rates were derived from the size distribution of a native brook trout population sampled in Roaring Creek (Preston County, West Virginia) during summer 1992. Roaring Creek is a third order (after Strahler 1957) tributary to the Cheat River, with a mean elevation of $715 \mathrm{~m}$ in the study area. The stream flows through forested limestone and sandstone deposits, with a pH range from 5.6 to 7.2 (Jordahl 1984). A $300 \mathrm{~m}$ reach was sampled with a backpack electroshocker, using a 3-pass removal method. Four cohorts were identified from fish lengths and weights recorded in the field, which roughly corresponded to age 0 , age 1 , age 2 , and age 3 and above.

The bioenergetics model of Hewett \& Johnson (1992) was calibrated to reproduce baseline growth rates observed in the Roaring Creek brook trout population from baseline stream temperatures recorded in a sample of West Virginia trout streams. The average weight of each size class was used as the initial weight in the simulations (Table 1), and the difference in the average weight between consecutive age classes was used as an estimate of annual growth. Annual growth rates and baseline stream temperatures were entered in the Hewett \& Johnson (1992) model to estimate total food intake (in grams) and to determine the feeding rate (P-value) for baseline temperatures. The P-value expresses food consumption as a percentage of the

Table 1. Initial weights $(g)$ of fish used in the simulations. The weights were measured in late May and early June

\begin{tabular}{|cc|ccc|}
\hline Cohort & Welght & Cohort & Weight \\
\hline Age 0 & 0.45 & & Age 2 & 30 \\
Age 1 & 13 & Age 3+ & 60 \\
\hline
\end{tabular}


maximum physiological potential; however, in this application, the $\mathrm{P}$-value represents relative prey availability, assuming that prey availability and feeding rates are correlated.

Water temperatures were measured bi-weekly from 1991 to 1992 with a mercury thermometer at 21 locations in the Shaver's Fork drainage of the Cheat River in Randolph County, West Virginia, by E. Dannaway (unpubl.). Water temperatures from Roaring Creek should be intermediate to the sample temperatures, since the elevation of Roaring Creek is intermediate to the sample elevations. The composite sample provides a more generalized characterization of central Appalachian trout stream temperatures than would Roaring Creek alone. The bi-weekly temperature measurements were averaged on each sampling date to produce a series of baseline temperatures for spring, summer, fall, and winter. Fish respond to a range of daily and diurnal temperature variation, which is removed by bi-weekly averages. Therefore, we extrapolated $3 \mathrm{~d}$ temperature averages from the bi-weekly means to increase the number of growth increments in the model and to create stochastic variation in the temperature series.

Twenty replicate temperature series were generated from the extrapolated $3 \mathrm{~d}$ means to simulate baseline temperatures, an increase of $2^{\circ} \mathrm{C}$ in the annual mean, and an increase of $4^{\circ} \mathrm{C}$ in the annual mean. Each replicate series consisted of 4 seasons ( 93 d periods) with 31 temperature values ( $3 \mathrm{~d}$ averages; Table 2 ). An algorithm was used to generate the temperature series from random number seeds using a Markov series (Davis 1986) and the average magnitude of temperature change observed between successive measurements. A Markov series calculates the probability of a transition from one state to another in an ordered set, based on observed transition frequencies from one state to another (Davis 1986). In a temperature series, there are 3 states that can occur; each consecutive observation must either increase, decrease, or remain the same as the previous observation (a temperature change greater than $\pm 0.5^{\circ} \mathrm{C}$ was considered to be an

Table 2. Temperatures used in the model were simulated for 31 periods of $3 \mathrm{~d}$ in each season. Average temperatures $\left({ }^{\circ} \mathrm{C}\right)$ are followed by the standard deviation in parentheses

\begin{tabular}{|lrrr|}
\hline Season & Baseline & \multicolumn{1}{c}{$+2^{\circ} \mathrm{C}$} & $+4^{\circ} \mathrm{C}$ \\
\hline Spring & $9.1(3.8)$ & $11.3(2.8)$ & $13.2(3.7)$ \\
Summer & $15.5(0.8)$ & $17.5(2.1)$ & $19.5(2.5)$ \\
Fall & $5.3(2.5)$ & $7.3(2.7)$ & $9.3(3.0)$ \\
Winter & $2.0(0.2)$ & $3.7(0.7)$ & $5.9(0.7)$ \\
Annual & $8.0(3.8)$ & $10.0(2.8)$ & $12.0(3.7)$ \\
\hline
\end{tabular}

increase or decrease in the model). We calculated the probabilities of each of these 3 outcomes in the Shaver's Fork data set and used the frequency distribution of the magnitude of change associated with each outcome to build the temperature algorithm. Seasonal temperature series were created by randomly assigning a starting temperature within $\pm 2^{\circ} \mathrm{C}$ of the average temperature observed on the first sampling date of each season. Each successive value in the series was assigned to one of the 3 transition states, based on the Markov probabilities. The magnitude of change was randomly drawn from the frequency distribution of observed temperature changes. The algorithm was constrained to keep the stream temperatures within a range in which brook trout would survive $\left(>0^{\circ} \mathrm{C}\right.$ and $<25^{\circ} \mathrm{C}$ ).

\section{BIOENERGETICS MODEL}

The bioenergetics model of Hewett \& Johnson (1992) was used in the simulations. The model is based on the balanced energy equation of Winberg (1956) where the energy used for growth is balanced with energy gained from consumption of prey and energy lost due to respiration, egestion, excretion, and digestion. Detailed explanations of the energetics model are found in Hewett \& Johnson (1992), and a general overview of bioenergetics is found in Adams \& Breck (1990). The Hewett \& Johnson (1992) model has alternative equations for modeling bioenergetics. We modeled egestion as a constant proportion of consumption, and excretion as a constant proportion of consumption minus egestion. The temperature-dependent function for consumption was obtained by fitting observations by Baldwin (1956) and McCormick et al. (1972) on brook trout consumption at different temperatures to the model of Thornton \& Lessem (1978). The Thornton \& Lessem (1978) model provides a good approximation for coldwater species (Hewett \& Johnson 1992) and has been used by Stewart et al. (1981) for other salmonids. The temperature function. for resting metabolism was modeled as exp(temperature $\times$ theta), where theta is the temperature-dependent constant. The value for theta was obtained using least-squares multiple regression with the observations reported by Job (1955) for brook trout respiration. Active metabolism was modeled as a fixed cost (or constant swimming speed).

Parameters for brook trout are not included in the Hewett \& Johnson (1992) model. Parameter values were derived from published literature on brook trout, or from values for lake trout Salvelinus namaycush used by Stewart et al. (1983) when brook trout values were not available (Table 3). All temperature-dependent functions used in the model were derived from 
Table 3. Model parameters used in the simulations (LT: lake trout; BT: brook trout). Detailed descriptions of variables are found in Hewett \& Johnson (1992)

\begin{tabular}{|c|c|c|c|c|}
\hline Variable & Description & Value & Species & Source \\
\hline \multicolumn{5}{|c|}{ Consumption } \\
\hline $\mathrm{CA}$ & Intercept for consumption & 0.059 & LT & Stewart et al. (1983) \\
\hline$C B$ & Weight-dependent consumption coefficient & -0.307 & $\mathrm{LT}$ & Stewart et al. (1983) \\
\hline$C Q$ & $\begin{array}{l}\text { Lower temperature where rate function } \\
=C K 1 \times \text { max. rate }\end{array}$ & $2.5^{\circ} \mathrm{C}$ & $\mathrm{BT}$ & McCormick et al. (1972) \\
\hline CTO & Lower limit of optimal temperature range & $12^{\circ} \mathrm{C}$ & BT & McCormick et al. (1972) \\
\hline CTM & Upper limit of optimal temperature range & $15^{\circ} \mathrm{C}$ & $\mathrm{BT}$ & Baldwin (1956) \\
\hline CTL & $\begin{array}{l}\text { Upper temperature where rate function } \\
=\text { CK } 4 \times \text { max. rate }\end{array}$ & $21^{\circ} \mathrm{C}$ & BT & Baldwin (1956) \\
\hline CK1 & Rate multiplier at $12^{\circ} \mathrm{C}$ & 0.1 & $\mathrm{BT}$ & Thornton \& Lessem (1.978) \\
\hline CK4 & Rate multiplier at $15^{\circ} \mathrm{C}$ & 0.1 & BT & Thornton \& Lessem (1978) \\
\hline \multicolumn{5}{|c|}{ Respiration } \\
\hline RA & Intercept for weight function & 0.001365 & BT & Job (1955) \\
\hline $\mathrm{RB}$ & Weight-dependence coefficient & -1.653 & BT & Job (1955) \\
\hline $\mathrm{RQ}$ & Temperature-dependence coefficient & 0.0821 & BT & Job (1955) \\
\hline RTO & Swimming speed $\left(\mathrm{cm} \mathrm{s}^{-1}\right)$ & 0.0232 & LT & Stewart et al. (1983) \\
\hline SDA & Specific dynamic action & 0.2882 & BT & Kerr (1971) \\
\hline \multicolumn{5}{|c|}{ Egestion and excretion } \\
\hline FA & Proportion of food egested & 0.212 & LT & Stewart et al. (1983) \\
\hline UA & Proportion of food excreted & 0.0314 & LT & Stewart et al. (1983) \\
\hline
\end{tabular}

brook trout data (Table 3). Fixed values for egestion and excretion are lake trout parameters (Table 3). Values for egestion and excretion are expressed as fixed proportions of consumption, and since they are constants, they do not affect rates of consumption or metabolism, or relative values compared in the model. Lake trout parameters were also used for weight-specific consumption rates (Table 3 ), which affect relative

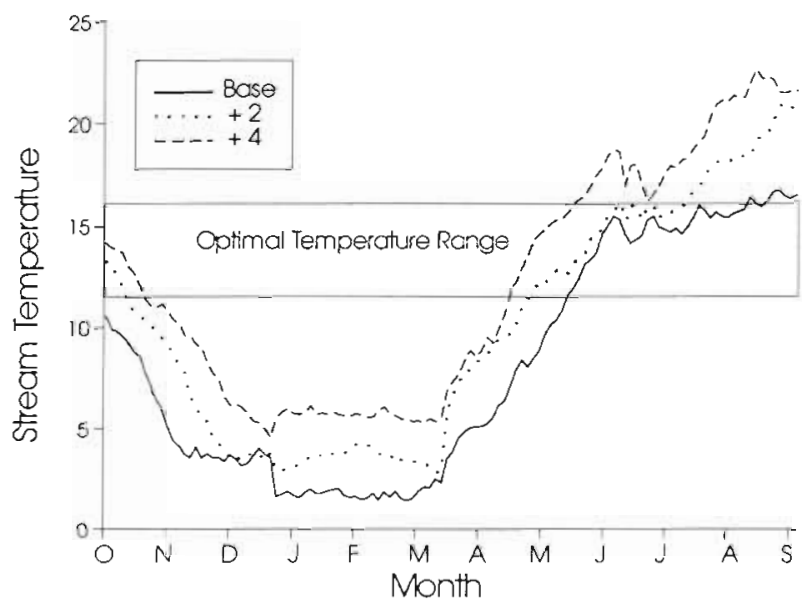

Fig. 1. Water temperatures $\left({ }^{\circ} \mathrm{C}\right)$ used in the simulations from October through September, and their relationship with the optimal temperature range for brook trout

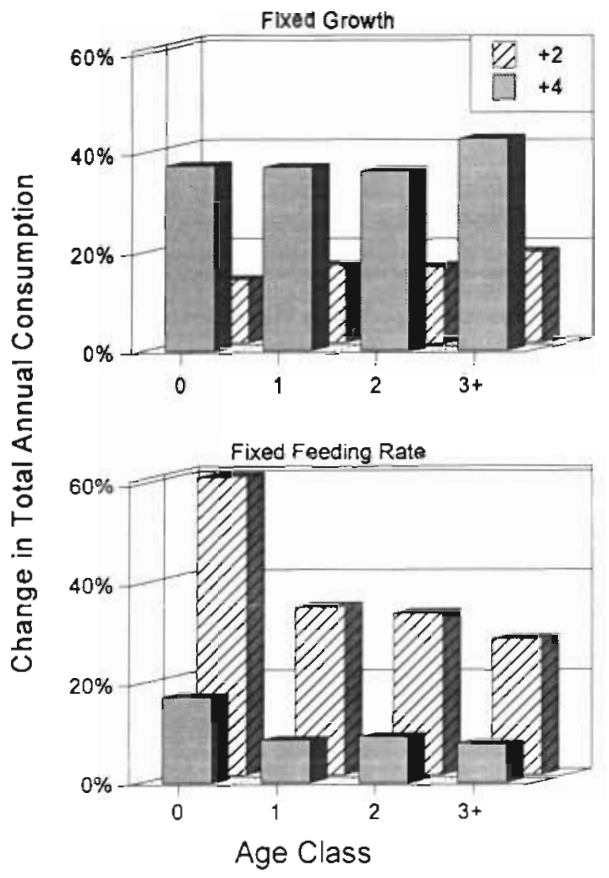

Fig. 2. Percent change in total annual consumption $\left(g \mathrm{~g}^{-1} x\right.$ 100) with $2^{\circ} \mathrm{C}$ and $4^{\circ} \mathrm{C}$ increases from baseline temperatures. Growth was fixed at baseline levels in the upper graph to show increased metabolic requirements. A fixed feeding rate (total intake/potential intake) in the lower graph shows the effects of temperature limitation 


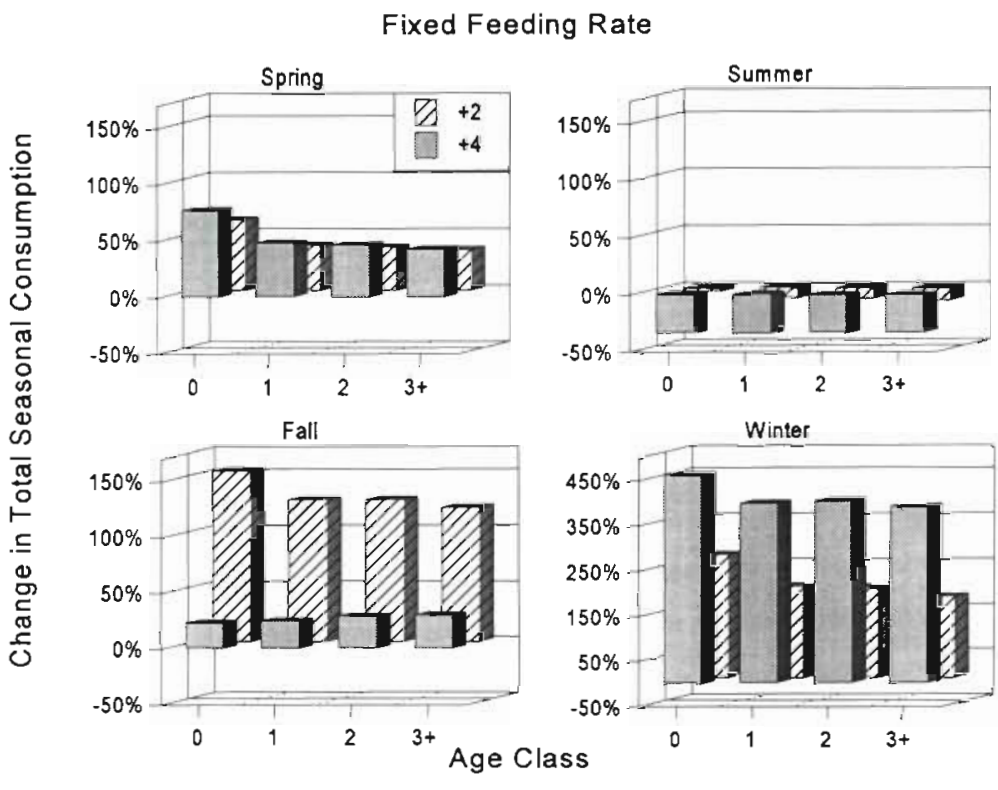
and $4^{\circ} \mathrm{C}$ increases from baseline temperatures and a fixed feeding rate (total intake/potential intake). Note different scale for winter
Fig. 3. Percent change in total seasonal consumption $\left(\mathrm{g} \mathrm{g}^{-1} \times 100\right)$ with $2^{\circ} \mathrm{C}$

rate, which varied with fish size and water temperature. A fixed P-value was used to model effects of temperature limitations on growth and consumption. Annual consumption increased by 36 to $66 \%$ at $+2^{\circ} \mathrm{C}$ and by 11 to $22 \%$ at $+4^{\circ} \mathrm{C}$. The magnitude of increase generally declined with increasing fish size (Fig 2). With higher temperatures, consumption declined in summer and increased in cooler seasons with a fixed P-value (Fig. 3). The greatest consumption increases occurred in winter, and in fall at $+2^{\circ} \mathrm{C}$ (Fig. 3).

When growth was fixed at baseline levels, total consumption increased with temperature, and larger fish were more strongly affected than smaller fish (Fig. 2). Consumption increased by 13 to $16 \%$ at $+2^{\circ} \mathrm{C}$ and by $37 \%$ at $+4^{\circ} \mathrm{C}$. Increases in consumption occurred during all 4 seasons, with the largest changes occurring in winter (Fig. 4). Increased prey may be available to brook trout if invertebrate production increases with temperature; otherwise, greater food differences in consumption between fish of different sizes, but do not affect relative differences in consumption due to temperature. Weight-specific consumption rates for brook trout and lake trout are likely to be very similar for the range of weights examined in the model. demand indicates an increasing risk of starvation as fish size and temperature increase.

Seasonal contributions to the annual diet were affected by increased temperatures when a fixed Pvalue was used and were largely unaffected when growth rates were constrained to baseline levels (Fig. 5). Under baseline conditions, 54\% of the total

\section{RESULTS}

On most dates throughout the year, water temperatures for all 3 annual means used in the simulations were lower than the optimal temperature range for brook trout reported by Baldwin (1956) and McCormick et al. (1972) (Fig. 1). Temperature increases of $2^{\circ} \mathrm{C}$ and $4^{\circ} \mathrm{C}$ moved water temperatures closer to the optimal range for brook trout from October through June, but the number of days within the optimal temperature range decreased, and temperatures exceeded $17^{\circ} \mathrm{C}$ in late summer (Fig. 1). Water temperatures were within the optimal range for brook trout for ca $90 \mathrm{~d}$ at baseline temperatures, ca $60 \mathrm{~d}$ at $+2^{\circ} \mathrm{C}$, and ca $50 \mathrm{~d}$ at $+4^{\circ} \mathrm{C}$ (Fig. 1). Water temperatures never exceeded $17^{\circ} \mathrm{C}$ at baseline, but exceeded optimal temperatures $\mathrm{ca}$ $45 \mathrm{~d}$ at $+2^{\circ} \mathrm{C}$, and ca $65 \mathrm{~d}$ at $+4^{\circ} \mathrm{C}$ (Fig. 1).

When a fixed $\mathrm{P}$-value was used, fish consumed a fixed proportion of their maximum

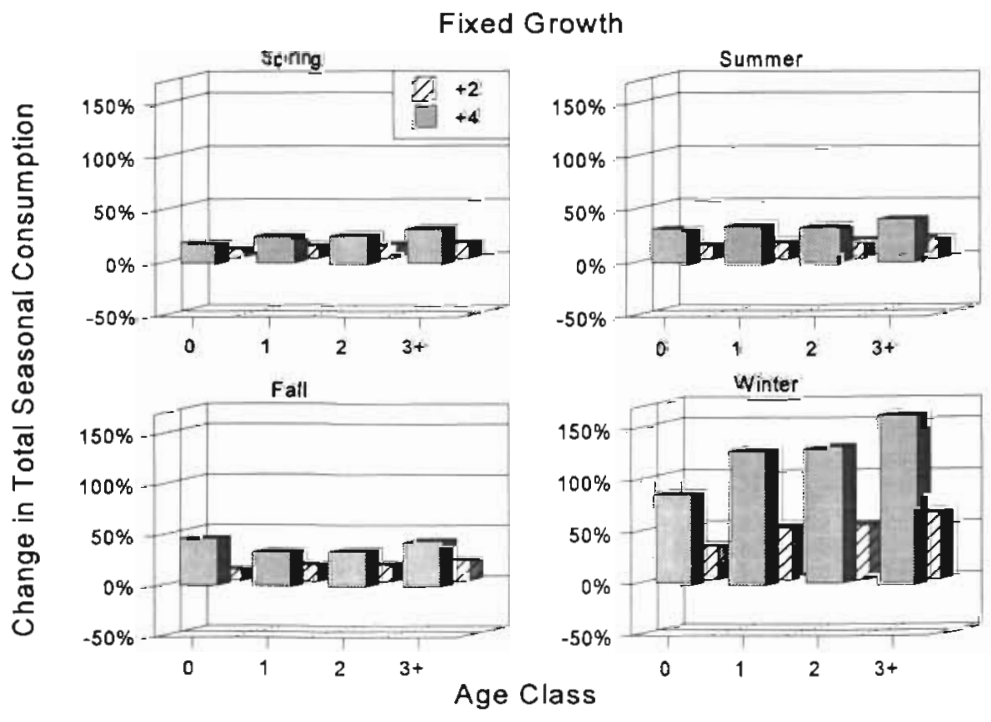

Fig. 4. Percent change in total seasonal consumption $\left(g g^{-1} \times 100\right)$ with $2^{\circ} \mathrm{C}$ and $4^{\circ} \mathrm{C}$ increases in the annual mean when growth was fixed at baseline levels. The change in consumption is a relative measure of starvation risk or increased productivity required to maintain present growth 


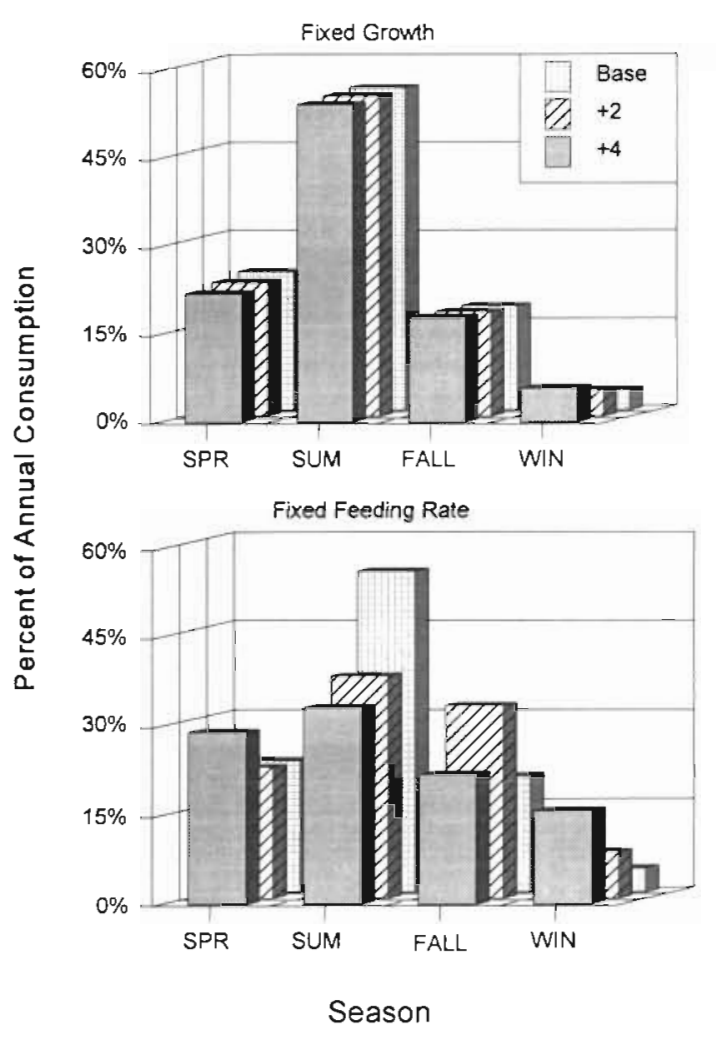

Fig. 5. Effect of temperature on the proportion of annual food consumption acquired each season. Growth was fixed at baseline levels in the upper figure, and the consumption rate ( $\mathrm{P}$-value) was fixed in the lower figure at $+4^{\circ} \mathrm{C}$ in winter (Fig 6). With a fixed P-value, annual growth was highest at $+2^{\circ} \mathrm{C}$, lowest at $+4^{\circ} \mathrm{C}$ for age 1 and age 2 fish, and lowest at baseline temperatures for age 0 fish (Fig. 7). Annual growth declined for all size classes with increasing fish size (Fig. 7). A $2^{\circ} \mathrm{C}$ increase in temperature increased annual food consumption and increased the number of calories available for growth for all size classes, compared with baseline levels. There was a smaller increase in annual consumption at $+4^{\circ} \mathrm{C}$ than at $+2^{\circ} \mathrm{C}$, in spite of higher metabolic demands. Consequently, fewer calories were available for growth at $+4^{\circ} \mathrm{C}$ for age 1 fish and above (Fig. 7). Growth rates increased for age 0 fish, and age 3 fish lost weight at $+4{ }^{\circ} \mathrm{C}$. With a fixed $\mathrm{P}$-value, increased temperatures caused a shift from temperature-limited growth at baseline temperatures toward optimal conditions at $+2^{\circ} \mathrm{C}$; a $4^{\circ} \mathrm{C}$ increase caused a shift from temperature-limited growth toward food-limited growth (with the exception of age 0 fish).

When growth was modeled with a fixed food ration, annual growth rates declined with increasing temperature and increasing fish size (Fig. 7). The decline in growth is an indication of temperature stress that occurs from food-limitation and from higher metabolic costs resulting from warmer temperatures. Larger fish are more susceptible to temperature stress than smaller fish. At $+2^{\circ} \mathrm{C}$, growth stagnated at age 3 ; while at $+4^{\circ} \mathrm{C}$, growth stagnated at age 2 , and age 3 fish would probably not survive with current food rations, as indicated by an annual weight loss of nearly $50 \%$ (Fig. 7). Higher temperatures caused growth rates to decline in all 4 seasons, with the greatest change in summer, at $+4^{\circ} \mathrm{C}$ (Fig. 8). prey consumed was eaten in summer, and $4 \%$ was eaten in winter. At increased temperatures, consumption was spread more evenly throughout the year. At $+4{ }^{\circ} \mathrm{C}$, summer consumption fell to $33 \%$ of the total annual consumption, and winter consumption rose to $16 \%$. Seasonal shifts in consumption represent temporal changes in feeding activities that would occur if food is available.

When growth was modeled with a fixed $\mathrm{P}$-value, higher temperatures tended to raise growth rates in colder seasons, and reduce growth rates in warmer seasons, indicating that growth is temperature-limited during cooler parts of the year. At baseline conditions, the greatest seasonal growth occurred in summer, followed by spring and fall, respectively (Fig. 6). All size classes lost weight at baseline conditions in winter. The highest seasonal growth rates occurred at $+2^{\circ} \mathrm{C}$ in spring and fall and

\section{Fixed Feeding Rate}

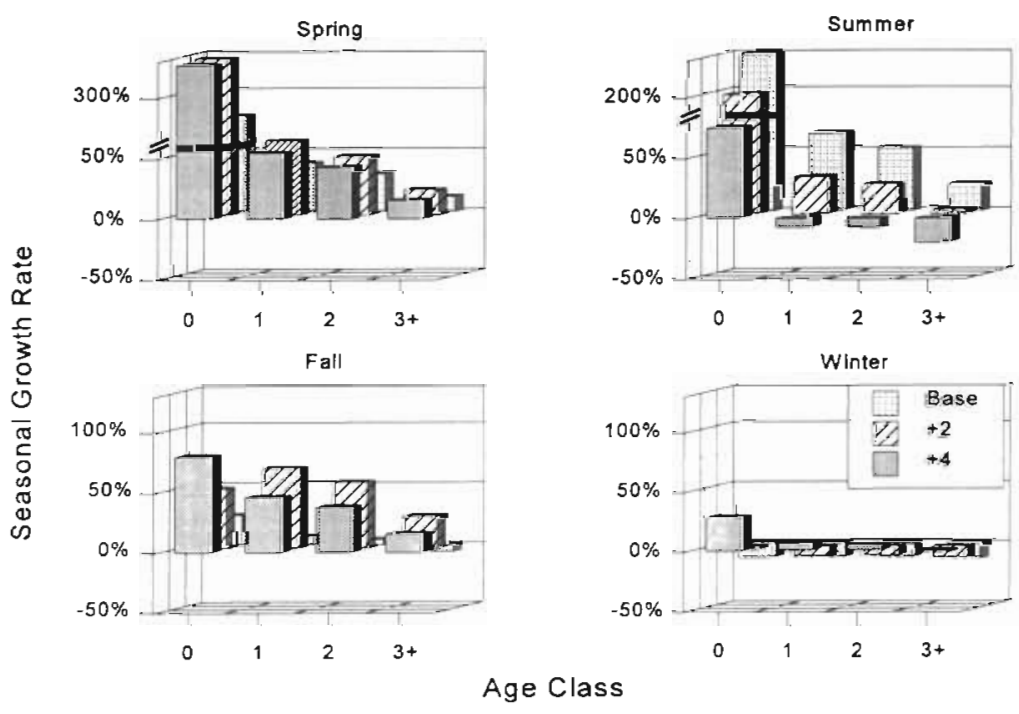

Fig. 6. Effect of temperature on seasonal growth rates when the consumption rate ( $\mathrm{P}$-value) is fixed. The $y$-axes are split in spring and summer to display values that exceed $100 \%$ (indicated by bars with solid bands) 


\section{DISCUSSION}

Regier \& Meisner (1990) surmised that brook trout populations limited by low temperatures at high latitudes and high elevations will benefit from warmer temperatures, and the opposite effect is predicted for brook trout populations at low latitudes and low elevations (Meisner 1990a, b). Brook trout populations at high elevations in the Appalachian Mountains are in the middle of these 2 extremes. Cada et al. (1987) attributed low trout productivity in southern Appalachian streams to a combination of temperature limitations at high elevations and food limitations in downstream locations. As a result of higher temperatures, the bioenergetics model predicts improved growth rates in high elevation Appalachian streams during spring and fall, and predicts lower growth rates and potentially lethal temperatures in summer. The overall effect of higher temperatures depends on food availability and the magnitude of temperature change assuming all other variables remain constant.

The bioenergetics model indicates that current growth rates of brook trout are temperature-limited at high elevations in West Virginia during much of the year. Cunjak et al. (1987) attributed weight losses of brook trout observed in 3 Ontario streams to temperature-limited consumption in fall and winter at temperatures comparable to those at high elevations in West Virginia. Brook trout could potentially benefit from increased tood consumption and growth with a moder-

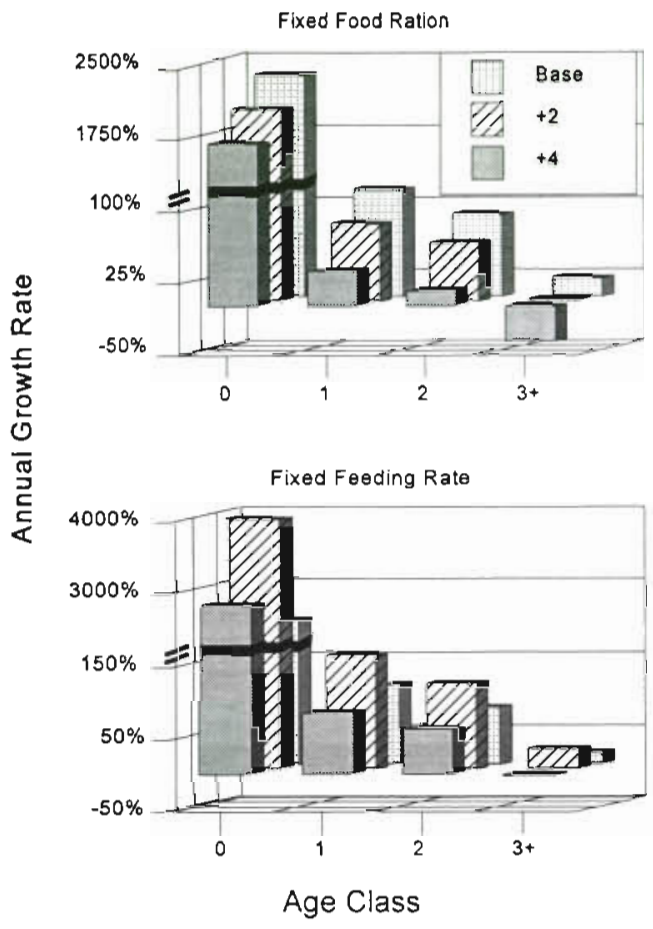

Fig. 7. Effect of temperature on annual growth rates. Total consumption (in $g$ ) was fixed at baseline levels in the upper figure. The consumption rate ( $\mathrm{P}$-value) was fixed in the lower figure. The $y$-axes are split to display values that exceed $100 \%$ in the upper figure, and $150 \%$ in the lower figure (indicated by bars with solid bands)

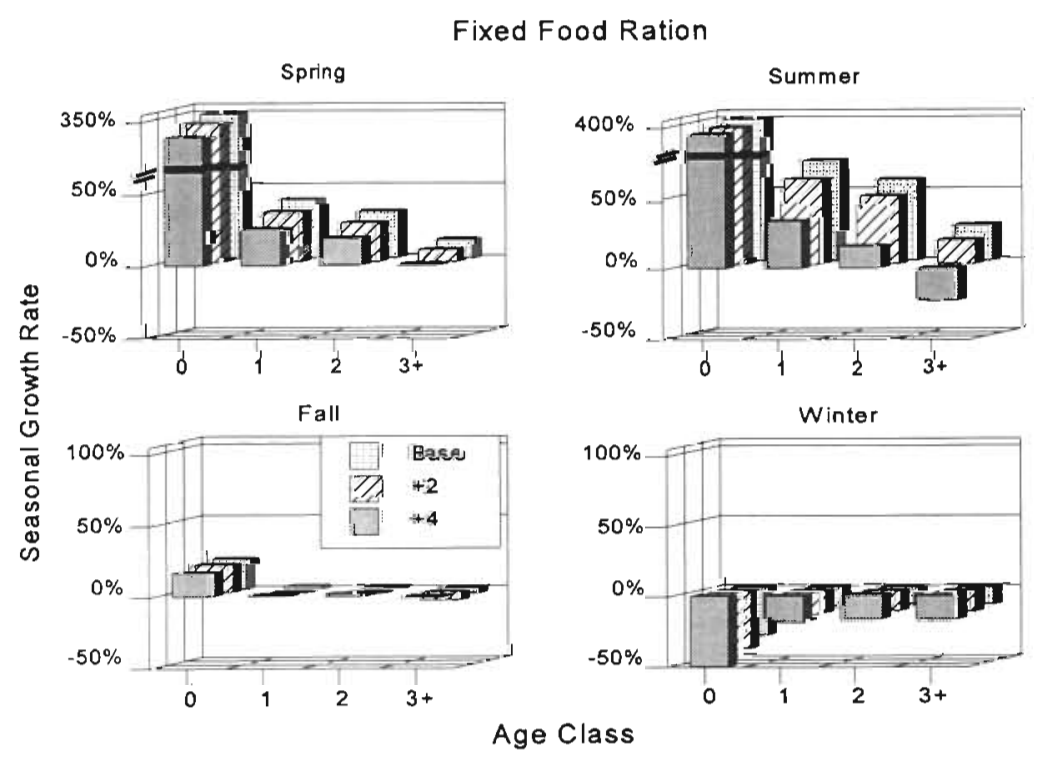

Fig. 8. Effect of temperature on seasonal growth rates when total consumption (in grams) is fixed at baseline levels. The $y$-axes are split in spring and summer to display values that exceed $100 \%$ (indicated by bars with solid bands) ate increase in temperature $\left(2^{\circ} \mathrm{C}\right.$ or less $)$ if food were available. With a moderate increase in temperature, reduced growth in summer could be offset by larger weight gains in spring and fall, resulting in an overall increase in growth. Food consumption would have to increase more than 15 to $20 \%$ to realize higher growth rates with a $2{ }^{\circ} \mathrm{C}$ increase in temperature.

With a $4^{\circ} \mathrm{C}$ increase in temperature, a larger P-value would have been necessary to maintain baseline growth beyond the first year. The P-value used in the simulations was fitted to reflect existing prey densities; therefore, a larger Pvalue indicates that food limitation would occur at present prey densities. An increase of $4^{\circ} \mathrm{C}$ would require a 30 to $40 \%$ increase in food consumption to reach present growth levels, and prey abundance could become a critical factor for survival. Prey abundance may limit growth of brook trout in summer near 
the southern margin of the range for brook trout. Summer food-limitation in a brook trout population was observed by Ensign et. al (1990) in mountainous Tennessee (USA) streams. Summer weight losses and population declines in Tennessee brook trout populations were attributed by Ensign et al. (1990) to food limitations, as indicated by caloric intake below maintenance levels.

Energetics of invertebrates, microbes, and algae are affected by temperature. Rates of production, maturation, and timing of invertebrate emergence could change with increased temperature. Based on the Arrhenius relationship of temperatures and rates of chemical reactions, primary production and invertebrate prey production is predicted to increase in aquatic ecosystems (Magnuson et al. 1989). Warmer temperatures may cause shifts in forest vegetation that could affect aquatic productivity and prey composition through changes in terrestrial inputs to a stream (Grimm 1993). The bioenergetics model indicated that dietary demands of brook trout would increase in spring and fall. Higher temperatures could shift the timing of invertebrate emergence or production and alter seasonal prey availability, obscuring or compounding energetic effects on brook trout. A shift in invertebrate composition from eutrophication in Lake Erie had a larger effect on fish growth than temperature differences in the lake (Hayward \& Margraf 1987).

The size and age structure of brook trout may also be affected by increased temperatures. The energetics model indicated that growth and survival rates of larger fish are more likely to decline as a result of high temperatures than those of smaller fish. Suitable habitat is more abundant for smaller-sized fish in headwater streams where brook trout are found in summer. Small fish can find cover in water that is too shallow for large fish, and therefore loss of thermal cover from increased temperatures will be more severe for large fish. Population viability would be threatened if brook trout could not reach adulthood.

We suggest that brook trout growth is optimized by an energetic 'strategy', where energy gains are maximized in summer and energy losses are minimized in winter under present conditions. Brook trout exhibit longitudinal shifts in stream distribution to seek favorable temperatures (Meisner 1990b), and they occupy separate habitats for feeding and overwintering (Chapman \& Bjornn 1969) that are energetically favorable. Feeding positions in locations where prey is concentrated by converging stream flow are selected by trout during summer to optimize the energetic return from feeding activity (Fausch 1984). In winter, brook trout move to areas of low water velocity to conserve energy (Gibson 1978). Energetic demands from activity in winter can greatly exceed the rate that energy is assimilated, due to reduced rates of digestion at low temperatures. Winter mortality and emigration of brook trout were reduced in a Wisconsin stream after the stream was altered to create deeper pools and a greater amount of cover (Hunt 1969).

At higher temperatures, brook trout might benefit from a strategy where energy losses are minimized in summer and winter, and energy gains are maximized in spring and fall. A brief period of time at high temperatures can have detrimental effects on brook trout because weight loss can occur very rapidly due to high rates of metabolism. Brook trout could minimize summer activity and seek refuge from high temperatures in summer, and move to higher velocity feeding locations in spring and fall when energetic costs are reduced, making energetic returns more profitable. Brook trout have the behavioral flexibility to adjust their activities and movements to changes in temperature. Brook trout populations worldwide exhibit an array of migratory movements in different directions and different times of the year to seek favorable temperatures (Scott \& Crossman 1973). In the Appalachian Mountains, there is limited opportunity for brook trout to move longitudinally to avoid summer temperatures. Since suitable temperatures for brook trout in many Appalachian streams are limited to the upper reaches, further upstream migration is restricted by impassable waterfalls and insufficient stream flows, and downstream migration is restricted by high water temperatures.

Brook trout populations at high elevations in the Appalachian Mountains could either benefit from increased growth rates in spring and fall, or suffer from shrinking habitat and reduced growth rates in summer, depending on the magnitude of temperature change and on food availability. It appears that an increase of $2^{\circ} \mathrm{C}$ or less could very likely increase brook trout growth, but the effect of larger temperature increases is less predictable, due to greater dependence on higher prey production. Ecosystem complexity makes it difficult to predict how food availability would be affected by warmer temperatures. The most predictable effect of higher temperatures is increased dependence of brook trout on deep pools, headwater streams, and springs. Stewardship of these habitats may curb the loss of brook trout populations from global warming in Appalachian streams.

Acknowledgements. This study was funded by the Fernow Experimental Forest, U.S. Forest Service, Northeastern Experiment Station, Parsons, West Virginia. We thank J. Margraf for technical assistance and critical comments; E. Dannaway, Department of Geology, West Virginia, and The West Virginia Department of Natural Resources for provicting stream temperature data; and T Chrnstiansen, S. Koenig and 2 anonymous reviewers for review and comments. This man- 
uscript is Scientific Article No. 2455 of the West Virginia Agriculture and Forestry Experiment Station. The West Virginia Conperative Fish and Wildlife Research Unit is jointly sponsored by the West Virginia Division of Natural Resources, West Virginia University, National Biological Service, and the Wildilife Management Institute.

\section{LITERATURE CITED}

Adams SM, Breck JE (1990) Bloenergetics. In: Schreck CB, Moyle PB (eds) Methods for fish biology. American Fisheries Society, Bethesda, MD, p 389-416

Baldwin NS (1956) Food consumption and growth of brook trout at different temperatures. Trans Am Fish Soc 68: $323-328$

Bivens RD, Strange RL, Peterson DC (1985) Current distribution of the native brook trout in the Appalachian region of Tennessee. J Tennessee Acad of Sci 60:101-105

Brett JR (1979) Environmental factors and growth. In: Hoar WS, Randall DJ, Brett JR (eds) Fish physiology, Vol 8. Academic Press, New York, p 599-675

Cada GF, Loar JM, Sale MJ (1987) Evidence of food limitation of rainbow and brown trout in southern Appalachian softwater streams. Trans Am. Fish Soc 1 16:692-702

Cess RD, Potter GL (1984) A commentary on the recent $\mathrm{CO}_{2}$ climate controversy. Clim Change 8:135-153

Chapman DW, Bjornn TC (1969) Distribution of salmonids in streams, with special reference to food and feeding. In Northcote TG (ed) Salmon and trout in streams. H. R MacMillan lectures in fisheries. University of British Columbia, Vancouver, p 153-176

Cunjak RA, Curry RA, Power G (1987) Seasonal energy budget of brook trout in streams: implications of a possible deficit in early winter. Trans Am Fish Soc 116 $817-828$

Davis JC (1986) Statistics and data analysis in geology, 2nd edn. John Wiley and Sons, New York

Elliott JM (1976) The energetics of feeding, metabolism and growth of brown trout Salmo trutta L. in relation to body weight, water temperature and ration size. J Anim Ecol 45:923-948

Ensign WE, Strange RJ, Moore SE (1990) Summer food limitation reduces brook trout biomass in a southern Appalachian stream. Trans Am Fish Soc 119:894-901

Fausch KD (1984) Profitable stream positions for salmonids: relating specific growth rate to net energy gain. Can J Zool 62:441-451

Fry FE, Hart JS, Walker EF (1946) Lethal temperature relations for a sample of young speckled trout, Salvelinus fontinalis. University of Toronto Biology Series 54, Publication of the Ontario Fisheries Research Laboratory, No. 66, Toronto

Gibson RJ (1978) The behavior of juvenile Atlantic salmon Salmo salar and brook trout Salvelinus fontinalis with regard to temperature and water velocity. Trans Am Fish Soc 107:703-712

Grımm NB (1993) Implications of climate change for stream communities. In: Kareiva PM, Kingsolver JG, Huey RB (eds) Biotic interactions and global change. Sinauer Associates, Sunderland, MA, p 239-314

Hayward RS, Margraf FJ (1987) Eutrophication effects on prey size and food available to yellow perch in Lake Erie. Trans Am Fish Soc 116:210-223

Hengeveld HG (1990) Global climate change: implications for air temperature and water supply in Canada. Trans Am Fish Soc 119:176-182
Hewett SW, Johnson BL (1992) A generalized bioenergetics model of fish growth for microcomputers (model 2). University of Wisconsin, Sea Grant Technical Report WIS-SG92-250, Madison

Hunt RL (1969) Effects of habitat alteration on production, standing crops and yield of brook trout in Lawrence Creek, Wisconsin. In: Northcote TG (ed) Salmon and trout in streams. H. R. MacMillan lectures in fisheres. University of Britush Columbia, Vancouver, p 218-312

Job SV (1955) The oxygen consumption of Salvelinus fontinalis. University of Toronto Biology Series 61, Publication of the Ontario Fisheries Research Laboratory No. 73 , Toronto

Jordahl DM (1984) Comparison of brook trout populations in an acidic, and a circumneutral stream. West Virginia Acad Sci 56:41-54

Kerr SR (1971) Analysis of experiments on growth efficiency of fishes. J Fish Res Bd Can 28:801-808

Kitchell JF, Stewart DJ, Weininger D (1977) Application of a bioenergetics model to yellow perch Perca flavescens and walleye Stizostedion vitreum vitreum. J Fish Res Bd Can $34: 1922-1935$

MacCrimmon HR, Campbell JS (1969) World distribution of brook trout Salvelinus fontinalis. J Fish Res Bd Can 26: $1699-1725$

Magnuson JJ, Hill DK, Regier HA, Holmes JA, Meisner JD. Shuter BJ (1989) Potential responses of Great Lakes fishes and their habitat to global warming. In: Smith JB, Tirpak DA (eds) The potential effects of global climate change on the United States. Appendix E, Aquatic resources. US EPA, EPA-230-05-89-055, Washington, DC, p 2-1-2-42

McCormick JH, Hokanson KEF, Jones BR (1972) Effects of temperature on growth and survival of young brook trout, Salvelinus fontinalis. J Fish Res Bd Can 29:1107-1112

Meisner JD (1990a) Effect of climatic warming on the southerin mângins of the native range uf brouk iruui, Saivelinus fontinalis. Can J Fish Aquat Sci 47:1065-1070

Meisner JD (1990b) Potential loss of thermal habitat for brook trout, due to climatic warming, in two Southern Ontario streams. Trans Am Fish Soc 119:282-291

Meisner JD, Rosenfeld JS, Regier HA (1988) The role of groundwater in the impact of climate warming on stream salmonines. Fisheries $13(3): 2-8$

Peterson RH, Sutterlin AM, Metcalfe JL (1979) Temperature preference of several species of Salmo and Salvelinus and some of their hybrids. J Fish Res Bd Can 36: $1137-1140$

Regier HA, Meisner JD (1990) Anticipated effects of climate change on freshwater fish and their habitat. Fisheries 15(6): 10-15

Rice JA, Breck JE, Bartell SM, Kitchell JF (1983) Evaluating the constraints of temperature, activity and consumption on growth of largemouth bass. Environ Biol Fish 9: $263-275$

Scott WB, Crossman EJ (1973) Freshwater fishes of Canada. Bull Fish Res Bd Can 180

Stewart DJ, Kitchell JF, Crowder LB (1981) Forage fish and their salmonid predators in Lake Michigan. Trans A.m Fish Soc 110:751-763

Stewart DJ, Weininger D, Rottiers DV, Edsall TA (1983) An energetics model for lake trout, Salvelinus namaycush: application to the Lake Michigan population. Can J Fish Aquat Sci 40:681-698

Strahler AN (1957) Quantitative analysis of watershed geomorphology. Trans Am Geophys Un 38:913-920

Thornton KW, Lessem AS (1978) A temperature algorithm for modifying biological rates. Trans Am Fish Soc 107:284-287 
Tonn WM (1990) Climate change and fish communities a conceptual framework. Trans Am Fish Soc 119:337-352 Winberg GG (1956) Rate of metabolism and food require-

Editor: V. Meentemeyer, Athens, Georgia, USA ments of fishes Belorussian University, Minsk. Translated from Russian: Fish Res Board of Can Translation Series 164, 1960, Ottawa

Manuscript first received: February 20, 1995

Revised version accepted: June 12, 1995 